\title{
An Investigating the Crucial Factors of Teachers' Efficacy from the Taiwanese School Member's Perspective
}

\author{
Mingchang $\mathrm{Wu}$ and Marsono
}

\begin{abstract}
The objectives of this study was to investigated in-depth understanding of teachers' efficacy by identifying the structural relationship of factors that influence teachers' efficacy in terms of principal's leadership, organizational commitment, social support, and psychological capital. A quantitative research design was conducted within purposive sampling method were used for data gathered from 204 high school teachers in Taiwan. The validated paper-pencil based questionnaires were employed in the study and analyzed undertaking descriptive analysis, confirmatory factor analysis (CFA), and structural equation modeling (SEM). Findings revealed that both principals' leadership and social support played a crucial role as a mediating factor that highly contributed to organizational commitment in enhancing teachers' efficacy. Finally, some suggestions were proposed for future research bridging theoretical and practical understandings of the formation and improvement of teachers' efficacy.
\end{abstract}

Index Terms-Organizational commitment, principals' leadership, psychological capital, social support, teachers' efficacy.

\section{INTRODUCTION}

\section{A. Research Background}

For people to choose as a teacher for their profession there can be a variety of reasons such as working conditions, salary, vacation time, and some intrinsic values which help them to take care of students [1]. In fact, school achievements fundamentally depend on its teachers' performance. As a means to maintaining the quality, three criteria in assessing the capability of teachers can be found: 1) whether or not a teacher can motivate students to learn, 2) whether or not a teacher can improve instructional effectiveness, and 3) whether or not a teacher can manage the learning environment.

As the recent literature shows, school leadership has become one of the most frequently studied topics in organizational sciences. The leadership style of a school principal is an influential determinant in the successful implementation of school administration [2]. Furthermore, other research findings in related organizational contexts have also indicated that a leadership style may favorably affect employees' well-being. Besides, several researches conducted in a variety of organizational contexts, including

Manuscript received September 23, 2015; revised November 25, 2015.

The authors are with the National Yunlin University of Science and Technology, the Department of Graduate School of Vocational and Technology Education, 123 University Rd. Section 3, Douliou, Yunlin 64002, Taiwan (e-mail: marsono.ft@um.ac.id). educational and non-educational ones, in different countries have further shown that leadership style might foster the employee motivational and work efficacy [3].

The correlation between organizational behavior and human resource management also seen as a critical challenge in the field of psychological capital. According [4], "leaders are who display positive behaviors are more likely to aid the development of their subordinate positive psychological capacities. Employees with higher psychological capital, engaging in greater creative behaviors, usually enhance the opportunities to produce creative outcomes." Therefore, leaders ought to give guidance regularly to employees in their routines as a supportive treatment in achieving organizational goals.

To achieve school goals, the school authorities should motivate teachers' efficacy in their working places. Teachers' commitment was positively correlated with teachers' belief in how they manage their classes well; how they conduct instructional design; and how they engage students to study [5]. Additionally, their efficacy was fostered by their commitment to the school and to their profession as a teacher. Moreover, [6] have emphasized that teachers' organizational commitment was positively affected by the shift of principals' leadership style. Therefore, this study was designed to identify the structure and influential paths of factors regarding teachers' efficacy.

\section{B. Objectives of the Study}

The purpose of this study was aimed to investigated in-depth understanding of teachers' efficacy by identifying the structural relationship of factors that influence teachers' efficacy in terms of principal's leadership, organizational commitment, social support, and psychological capital, for enhance the effectiveness of teachers' efficacy, from the perspective of school principals and teachers of in Taiwan.

\section{Relevant Scholarship}

\section{1) Teachers' efficacy}

Teachers' beliefs are essential to the quality of teaching activities because their beliefs are directly associated with their competency and teaching motivation [7]. On the other hand, efficacy is a teacher's belief in their own competencies to influence and motivate students in learning activities, including some endeavors in overcoming obstacles and failures to enhance the academic achievements [8]-[10].

Further research [11] supported the notion by emphasizing that teachers' competency would have a constructive effect on student activities for learning. To do so, there are six domains of qualified teachers: 1) prerequisites of effective teaching; 2) personal characteristics; 3) management of the classroom; 4) 
instructional planning; 5) instructional delivery; and 6) assessment.

Furthermore, [12] have proposed several dimensions of assessment on teachers' efficacy: 1) student engagement; 2) instructional strategies; and 3) classroom management. Besides, [13] believes that a teacher with higher Personal Teaching Efficacy (PTE) will have better strategies for employing effective teaching, sufficient of pedagogical competencies, handling the troubled students gently, and taking care of positive changes in student learning activities. Then, teachers with high PTE tend to express a great level of enthusiasm in classroom activities, including more creative ideas, or methods in motivating students [14], [15].

\section{2) Principals' leadership}

Leadership is "an influence relationship among leaders and followers who intend real changes that reflect their mutual purposes" [16]. Besides, [17] stated that leadership is a process of motivating people to work together in collaborative ways to accomplish great things.

School leadership seen as having a bureaucratic thinking and philosophy taken from scientific management principles [18]. Leaders of the teachers were viewed as an extension of traditional school administrations [19]. In the past, such a role was designed to ensure the efficiency and effectiveness of an existing system [20]. Leaders of teachers, therefore, shifted from a managerial role to become various instructors.

The roles of teacher leadership include teachers as team leaders, developers of academic curriculum, professional development providers, and mentors for new teachers. Although such viewpoint has acknowledged the pedagogical expertise of teachers, these roles are intended to be "apart from" rather than "a part of" teachers' daily activities [21]. Thus, teacher leaders attempt to promote several instructional improvements by reshaping the school culture to perform stronger supports on a collaborative and continuous learning environment [22].

According to [23], five practices of exemplary leadership need to be exercised including: "1) modeling the way in earning required rights and respects to lead through supportive relationships and in demonstrating exemplary behaviors to follow; 2) inspiring a shared vision when leaders get to know their constituents, speak their language, and genuinely have their deep interests; 3) pioneering leaders challenge the process by stepping out into the unknown and searching for opportunities to innovate, grow, and improve; 4) enabling others to act by fostering collaboration and building trust; and 5) encouraging successful relationships between leaders and their constituents".

\section{3) Psychological capital}

Psychological capital refers to "an individual's positive psychological state of development that is characterized by a) having confidence (efficacy) to take on and put in the necessary effort to succeed at challenging tasks; b) persevering toward goals and, when necessary, redirecting paths to goals (hope) in order to succeed; c) making a positive attribution (optimism) about succeeding now and in the future; and d) when beset by problems and adversity, sustaining and bouncing back and even beyond (resilience) to attain success" [24].
Psychological capital affects employees' perceptions and emotions which may further increase their motivation to do challenging and meaningful works [25]. Furthermore, [26] argue that psychological capital may enhance employees' performance. In addition, [27] propose their notion in which psychological capital is tightly related to an employee's performance.

In many ways, psychological capital may have a strong contribution in creating a situation that stimulates the quality of work-related life needs, i.e. survival, belonging, and knowledge, as well as the employees' performance [28].

\section{4) Social support}

Previous scholar, [29] have recommended and developed the three construct of commitments, which consists of affective commitments, continuance commitments, and normative commitments. Social support has two functions that focused on meeting workers' need to feel valued, cared for, respected, provides workers with practical assistance in term of their roles, responsibilities, and task [30]. Studies from 349 employments, [31] found that results of structural equation modelling analysis reveal significant relationships between coworker support and organizational commitment.

In addition, [32] proved that organizational support positively influenced commitment of the organization members. In terms of perceived organizational support, teachers who get higher support from their societies tend to more commitment to their organization [33].

\section{5) Organizational commitment}

Many kinds of institution were included investigation on organizational commitment in their research field. One of those is an educational institution. Organizational commitment in an educational institution is stated as a constant process taken by teachers to show they are better in every situation that may indicate their contributions to the organization [34]-[36].

Furthermore, [37] have identified organizational commitment have several basic components in potential teacher's belief and acquiring of the school's objective. These include how teacher's motivations give a positive impact on their loyalty in the organizational activities, also to perform of their efforts on achieving organizational goals. Moreover, [29] have conceptualized organizational commitment into three dimensions, i.e. "1) Affective Commitment which refers to employee's emotional attachment to, identification with, and involvement in an organization; 2) Continuance Commitment that refers to employee's attentiveness to any cost associated with leaving an organization; and 3) Normative Commitment which reflects to employee's feelings of obligation to continue one's employment in an organization".

\section{Research Questions}

The present study aims to investigating the ways in which these factors may simultaneously create interactive effects in a real educational setting. Therefore, the following research questions were consequently postulated in a real workplace:

1) What are the fixed constructs among psychological capital, principals' leadership, social support, organizational commitment, and teachers' efficacy to meet the good structural model criteria? 
2) There is any correlation among psychological capital, principals' leadership, social support, organizational commitment, and teachers' efficacy?

3) How psychological capital, principals' leadership, social support, organizational commitment predicts teachers' efficacy?

\section{E. The Limits of the Study}

This study was limited to the Taiwanese certified teachers in public senior high schools as a research population and sampling procedures. The number of participants were according to the statistical data from Taiwan Ministry of Education (www.moe.gov.tw). The questionnaires were gathered from school principals and the teachers' perspective.

\section{RESEARCH METHODS}

\section{A. Conceptual Framework}

This study was quantitative research design with paper-pencil based questionnaire to identify the structure and influential paths of factors regarding teachers' efficacy. As the abovementioned literature has indicated, leadership bears a significant relationship with psychological capital and there are strong positive relationships between supervisor's leadership and psychological capital; moreover, leadership is diverse due to the commitment of the organizational members [38]. Leadership plays a decisive role in preserving a higher organizational commitment among employees, and leadership therefore becomes an important determinant of organizational efficacy [39]. Similarly, the leadership of the school leaders has strong and significant relationships with teachers' self-efficacy [40]. The commitment of the workers [41] and the levels of their positive psychological capital [42] also affected employees' efficacy.

In short, there is a close relation among teachers' efficacy, principals' leadership, psychological capital, social support and organizational commitment. However, it was clear from the former analysis about the interrelation of the correlative variables that clear knowledge about how these five interact is still lacking.

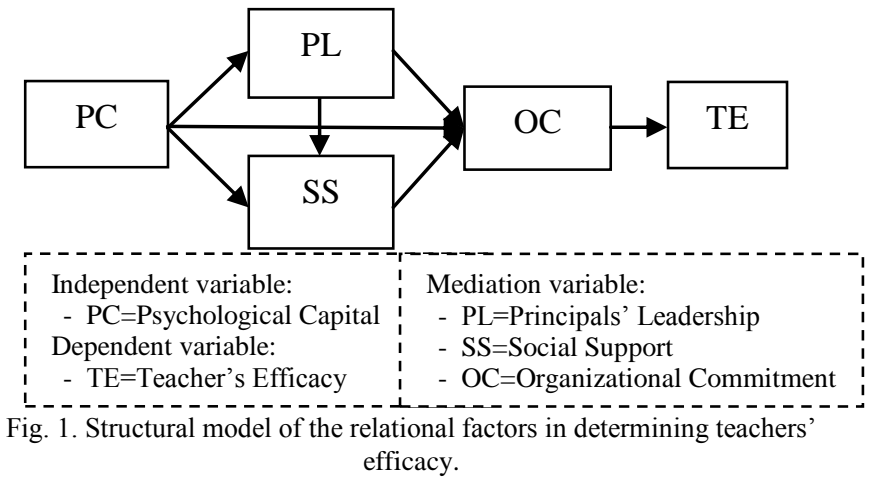

\section{B. Population and Sampling Procedures}

The target population of the present study was public senior high school teacher in Taiwan who possess professional certificates. Data were collected through paper-pencil based questionnaires.

There were 1,070 public senior high school teacher in
Taiwan within professional certificates teachers. Hence, using a confidence level of $95 \%$ (which will give a margin error of 0.05 ) the total sample that representing the population are 290 teachers. Taking the responsibility of a number of questionnaire error, this study selected 300 teachers for the data collection.

\section{Data Collection and Data Analysis}

The data collection was selected 300 Taiwanese high school members including principals and teacher as participants and within 2-week period 223 questionnaires were returned, it was equivalent to $74 \%$ response rate. Among these returned questionnaires, 204 questionnaires were stated as completed and therefore taken as the data for the subsequent analyses.

The collected data were analyzed by means of the SPSS 18 and AMOS 20 statistics software package, undertaking descriptive analysis, confirmatory factor analysis, and structural equation modeling (SEM) for all of the variables.

\section{Study Instruments}

Composite questionnaires were employed to collect the data on this study. There were 58 items adapted from five existing validated questionnaires, including teachers' efficacy, organizational commitment, psychological capital, principals' leadership, and social support. All items are converting into Chinese language version and taking content validity from professional Taiwanese teachers.

\section{1) Constructs of teachers' efficacy}

The Ohio State Teacher Efficacy Scale (OSTES) was first developed by [12] and it is widely used to measure teachers' efficacy. Participants were asked to describe their efficacy on a 12-item scale. A five-point Likert scale was used with the responses ranging from ( $1=$ nothing; to $5=$ a great deal). In the OSTES, teachers' efficacy is measured via the use of the three constructs. The constructs were measured by four items for each, such as efficacy in student engagement (for example, I give motivation to the students), instructional strategies (for example, I use a variety of assessment strategies), and classroom management (for example, I control disruptive behavior in the classroom). Every factor's Cronbach' $\alpha$ coefficient is $0.81,0.86$, and 0.86 respectively. This instrument was validated to possess high reliability for whole instrument $(\alpha=0.90)$.

\section{2) Constructs of organizational commitment}

The Organizational Commitment Questionnaire (OCS) was first developed and validated by [29]. In this study, it was employed to measure the teachers' perspectives on organizational commitment. This self-rating questionnaire contained 10 items to measure three detailed constructs, including affective commitment (4 items; for example, I am feel 'emotionally attached' to this organization), continuance commitment (4 items; for example, it is hard for me to leave my organization), and normative commitment ( 2 items; for example, I believe loyalty to the organization is important). Ratings are complete on a five-point Likert scale ( $1=$ Strongly Disagree; to 5= Strongly Agree). The questionnaires had been tested and obtained Cronbach's alpha 0.87, 0.75, and 0.79 respectively for each factors. In other words, the instrument had been proven valid. 


\section{3) Constructs of psychological capital}

This study adopted the PsyCap Questionnaire (DPCQ) developed by [43], under the background of educational organization, some content and words being revised. At last, the questionnaire remained 12 items to identify specific teachers' psychological capital related to optimism (4 items; for example, I always find that every problem has a solution), hope (4 items; for example, I am energetic to accomplish the work goal), and resilience (4 items; for example, I am encouraged and ready to face with difficulties at work). This assessment had been tested as having a good validity and reliability based on its Cronbach's alpha measurement for each factors $0.80,0.84$, and 0.87 respectively.

\section{4) Constructs of principals' leadership}

The principals' leadership questionnaire was first proposed by [23] in order to firmly measure principals' leadership. It contained 12 items, including how principals inspire a shared vision (6 items; for example, I appeal to others to share an exciting dream of the future) and enable others to act (6 items; for example, I support the decisions that people make on their own) in a senior high school. This short-form scale had been proven to have an internal consistency coefficient $(0.95$ and 0.91), based on Cronbach's alpha measurement which indicated its validity and reliability as a research instrument.

\section{5) Constructs of social support}

This study adopted a Social Support Scale (SSC) questionnaire developed by [44] to collect the data about teachers' social support both from their supervisor and from co-worker. It had 12 items including how their supervisor gives the support (6 items; for example, my supervisor appreciates the work that I do) and support from their co-worker ( 6 items; for example, my co-workers are willing to listen to my personal problems). A five-point Likert scale was used with the responses ranging from ( $1=$ Strongly Disagree; to 5= Strongly Agree). The questionnaires had been tested as having Cronbach's alpha 0.92 , and 0.90 respectively for each factors.

\section{RESEARCH FINDING}

\section{A. Respondents' Demographic Backgrounds Analysis}

These respondents' demographic backgrounds were analyzed as in the Table I. Most of the respondents possessed over 5 years of teaching experience $(77.9 \%)$.

TABLE I: SAMPLES' DEMOGRAPHIC BACKGROUNDS ( $N=204)$

\begin{tabular}{c|c|c|c|c|c|c}
\multicolumn{2}{|c|}{ TABLE I: SAMPLES' DEMOGRAPHIC BACKGROUNDS $(N=204)$} \\
\hline & \multicolumn{2}{|c|}{ Gender } & \multicolumn{4}{|c}{ Working experience (years) } \\
\hline & Male & Female & Under 5 & $6 \sim 10$ & $11 \sim 15$ & Over 16 \\
\hline$N$ & 122 & 82 & 45 & 42 & 52 & 63 \\
\hline$\%$ & 59.8 & 40.2 & 22.1 & 20.6 & 26.5 & 30.9 \\
\hline
\end{tabular}

\section{B. Reliabilities and Validities Instruments in This Study}

The examination of the reliability and validity of the instruments employed in this study indicated that all factor loadings were above 0.65 (between $0.67 \sim 0.94$ ), which is significant among the constructs and variables. This indicates that most of the constructs were the good indicators of all variables. All constructs were thus justified as reliable (Table II) as having Cronbach's $\alpha$ between $0.664 \sim 0.898$, suggesting that most of the items have relatively high internal consistency. The composite reliability (CR) values of teachers' efficacy, organizational commitment, psychological capital, social support, and principals' leadership were $0.81,0.78,0.90,0.68$, and 0.93 , respectively. This demonstrates a high internal consistency $(>0.60)$ of these latent variables signifying that the variance in the indicators were explained by the common factor, and average trait-related variance were extracted.

Moreover, the convergent and discriminant validities were examined by using Average Variance Extracted (AVE). In this study, all AVEs exceeded the threshold of $0.5(0.58,0.53$, $0.76,0.51$, and 0.87 , respectively) which indicated that this study had adequate convergent and discriminant validities [45]. These measurements were stated as reliable and valid.

\section{Correlations among Five Variables}

The analyses on Pearson's product-moment correlation coefficient were significantly positive of linear dependence among the five variables $\left(0.247^{* *} \sim 0.616^{* *}\right)$, except the correlation between teachers' efficacy and social support $(0.1)$ (Table III).

TABLE II: FACTOR LOADING, CRONBACH'S A, AVE, AND CR

\begin{tabular}{lcccc}
\hline Variables & $\begin{array}{c}\text { Factor } \\
\text { Loading }\end{array}$ & AVE & CR & $\begin{array}{c}\text { Cronbach's } \\
\boldsymbol{\alpha}\end{array}$ \\
\hline Principals' Leadership & & 0.87 & 0.93 & 0.806 \\
- Inspire a Shared Vision & 0.92 & & & \\
- Enable Others to Act & 0.94 & & & \\
\hline Social Support & & 0.51 & 0.68 & 0.898 \\
- Co-worker Support & 0.67 & & & \\
- Supervisor Support & 0.76 & & & \\
\hline Psychological Capital & & 0.76 & 0.90 & 0.664 \\
- Optimism & 0.90 & & & \\
- Hope & 0.86 & & & \\
- Resilience & 0.85 & & & \\
\hline Organizational Commitment & & 0.53 & 0.78 & 0.820 \\
- Normative Commitment & 0.74 & & & \\
- Continuance Commitment & 0.68 & & & \\
- Affective Commitment & 0.78 & & & \\
\hline Teachers' Efficacy & & 0.58 & 0.81 & 0.806 \\
- Student Engagement & 0.74 & & & \\
- Instructional Strategies & 0.73 & & & \\
- Classroom Management & 0.82 & & & \\
\hline
\end{tabular}

TABLE III: CORRELATION AMONG FIVE VARIABLES

\begin{tabular}{|c|c|c|c|c|c|}
\hline Variables & 1 & 2 & 3 & 4 & 5 \\
\hline 1. Teachers' Efficacy & 1 & & & & \\
\hline $\begin{array}{l}\text { 2. Organizational } \\
\text { Commitment }\end{array}$ & $.368^{* *}$ & 1 & & & \\
\hline 3. Psychological Capital & $.418^{* *}$ & $.537^{* *}$ & 1 & & \\
\hline 4. Social Support & .100 & $.508^{* *}$ & $.411^{* *}$ & 1 & \\
\hline 5. Principals' Leadership & $.247^{* *}$ & $.528^{* * *}$ & $.377^{* *}$ & $.616^{* *}$ & 1 \\
\hline
\end{tabular}

The strength of the correlation within the weak correlation (0.1 0.3), moderate correlation $(0.3 \sim 0.5)$, and strong correlation (>5), this study showed moderate correlations existing between teachers' efficacy with organizational commitment $(0.368 * *)$, and psychological capital $\left(0.418^{* *}\right)$, also between psychological capital with social support $\left(0.411^{* *}\right)$, and principals' leadership $\left(0.377^{* *}\right)$. Additionally, there were high correlations between social support and principals' leadership $\left(0.616^{* *}\right)$, organizational commitment 
and psychological capital $\left(0.537^{* *}\right)$, organizational commitment and social support $\left(0.508^{* *}\right)$, and organizational commitment and principals' leadership $\left(0.528^{* *}\right)$.

\section{Structural Model}

In order to investigate the linear structural relationship of the five latent variables for teachers' efficacy as dependent variable in senior high school settings, this study reported only selected group of fit statistics. The goodness-of-fits of the structural model (Table IV), including the Goodness-of-Fit Index (GFI), Adjusted Goodness-of-Fit Index (AGFI), Normed Fit Index (NFI), Comparative Fit Index (CFI), and Root Mean Square Error of Approximation (RMSEA), were also assessed in this study to identify the structure model fitness within variables. The statistical examination of these additional hypotheses is intended to identify and clarify the mediation mechanism or influential paths that may denote the observed relationships between independent variables and dependent variables [46].

TABLE IV: SELECTED AMOS OUTPUT FOR FIVE FACTORS OF MODEL FITNESS

\begin{tabular}{ccccl}
\hline Indices & Model fitness & Criteria & Result & Reference \\
\hline Chi-square & $\begin{array}{c}119.447 \\
(p=0.000)\end{array}$ & $\begin{array}{c}P<0.001 ; \\
\text { H0=rejected }\end{array}$ & H0=rejected $\begin{array}{l}\text { Bollen } \\
(1989)\end{array}$ \\
\hline $\begin{array}{c}\text { Chi-square / } \\
\text { df }\end{array}$ & 2.212 & $<5$ & Accept & $\begin{array}{l}\text { Jöreskog \& } \\
\text { Sörbom } \\
(1993)\end{array}$ \\
\hline GFI & 0.918 & $0.8 \sim 1$ & Accept & $\begin{array}{l}\text { Hu \& } \\
\text { Bentler } \\
(1999)\end{array}$ \\
\hline AGFI & 0.861 & $0.8 \sim 1$ & Accept & $\begin{array}{l}\text { Anderson \& } \\
\text { Gerbing } \\
(1984)\end{array}$ \\
\hline NFI & 0.927 & $0.8 \sim 1$ & Accept & $\begin{array}{l}\text { Bentler \& } \\
\text { Bonnett } \\
(1980)\end{array}$ \\
\hline CFI & 0.958 & $0.8 \sim 1$ & Accept & $\begin{array}{l}\text { Bentler } \\
(1990)\end{array}$ \\
\hline & & & & $\begin{array}{l}\text { Hu \& } \\
\text { Bentler } \\
(1999)\end{array}$ \\
\hline
\end{tabular}

This study revealed that the fit of data to the hypothesized model is not entirely adequate (Chi-square value of 119.447 , with a probability of less than $0.001(p<0.001)$. Interpreted accurately, this test statistic indicates represents an unlikely event the null hypothesis should be rejected. However, based on the Goodness-of-Fit Index (GFI) and Adjusted Goodness-of-Fit Index (AGFI) values (0.918 and 0.861, respectively), these assessments concluded that this hypothesized model fitted the sample data fairly well.

The Comparative Fit Index (CFI) (0.958) indicated that the model fitted of the data well in the sense that the hypothesized model adequately described the sample data. In somewhat less glowing terms, the Normed Fit Index (NFI) value suggested that model fit was only marginally adequate $(0.927)$ Table $\mathrm{V}$ shows that the root means square error of approximation (RMSEA) value for our hypothesized model is 0.077. Interpretation of the confidence interval consequently indicates that the true RMSEA value in the population was represented a good degree of precision.

The analysis produced the detailed overview of the mediation effect on teachers' efficacy (Fig. 2). The results indicated principals' leadership has a higher coefficient $(0.41)$ than social support, organizational commitment, and teacher efficacy $(0.23,0.35$, and 0.31 , respectively) to psychological capital. Additionally, social support gives the highest coefficient $(0.70)$ to principals' leadership, as mediating factor of psychological capital, rather than organizational commitment (0.12) and teachers' efficacy (0.37). Organizational commitment (0.70) played a crucial role as mediator by its domination over the effect to principals' leadership, social support, and psychological capital on teachers' efficacy.

\section{E. Summary of Research Findings}

Based on the aforementioned analyses, the findings of proposed research questions are follow:

\section{1) The first question}

What are the fixed constructs among psychological capital, principals' leadership, social support, organizational commitment, and teachers' efficacy to meet the good structural model criteria?

To answer this question, this study used the factor loading value from confirmatory factor analysis of psychological capital, principals' leadership, social support, organizational commitment, and teachers' efficacy as shown in Table II above.

It is clear from the Table II above, the result shows fixed construct for each variables, as follow: 1) principals' leadership have two constructs (inspire a shared vision and enable others to act); 2) social support can be seen from co-worker and supervisor support; 3) psychological capital have three constructs: optimism, hope, and resilience; 4) organizational commitment have three constructs (normative, continuance, and affective commitment); and 5) teachers' efficacy have three constructs: efficacy in student engagement, instructional strategies, and classroom management.

\section{2) The second question}

There is any correlation among psychological capital, principals' leadership, social support, organizational commitment, and teachers' efficacy?

The results of Pearson's product-moment correlation coefficient were solving the second research questions. From Table III above, this study concluded that there is significantly positive correlation among variables, except the correlation between teachers' efficacy and social support. It is clear that, there are inter-correlation among each variable. In other word, changing any variable value will give effect on the other variables.

These correlations suggested that in senior high school settings, these variables (teachers' efficacy, organizational commitment, psychological capital, social support, and principals' leadership) were tightly related to and interdependent on each other. In other words, most of these correlation coefficients with positive values indicates that any slight change in one variable corresponds to an increase in the other.

3) The third question 
How psychological capital, principals' leadership, social support, organizational commitment predicts teachers' efficacy?

The fixed model fitness output of SEM on Fig. 2 and Table IV above are adequate in order to answer this question. Most of the model fitness criteria were accepted on the fixed models. The result indicate that psychological capital have high loading on principals' leadership rather than on others variables. Principals' leadership have high loading on social support variable instead of organization commitment and teachers' efficacy. Social support has positive loading to organization commitment. Organizational commitment is therefore another key factor in mediating psychological capital, principals' leadership, and social support to predict the teachers' efficacy.

These phenomena demonstrated that teachers' efficacy was affected and continuously intervened through multilevel mediation effects of these five constructs instead of being directly influenced by any factor. Furthermore, the results confirmed the social interaction theory that efficacy was established and transformed through individuals' interaction with factors in their environment [47].

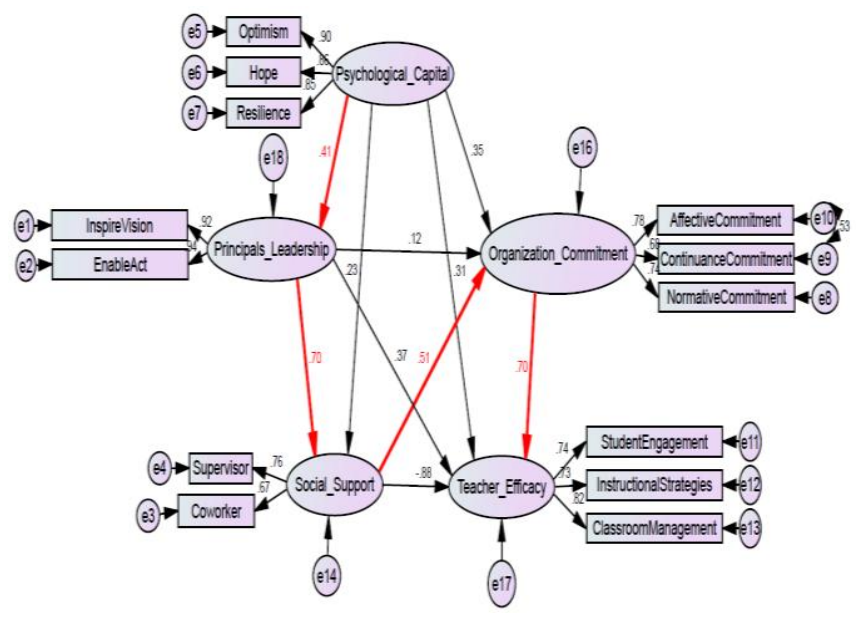

Fig. 2. The multilevel mediation model of the constructs.

\section{Discussion AND SUGGESTION}

This empirical study was designed to investigate the structural relationships among individual internal and external factors influencing teachers' efficacy at the senior high school level. Particularly, the mediating effects resulting from principals' leadership, social support, and organizational commitment on teachers' efficacy were intensively examined to identify any possible influential approach and effect on the teachers' efficacy.

\section{A. Discussion}

Findings indicate that teachers' efficacy is established and transformed through continuous interactions among the five constructs, confirming Bandura's social learning theory [48], [8]. With multilevel mediation effects, several noteworthy issues were consequently raised from the study. The high correlations exist among the five constructs and demonstrate a perfect mutualistic symbiosis. The mutualism reflects the facts that these constructs highly concerned in school settings are interdependent and contextually coexistent in the teachers' perspectives. Besides, this fact also confirms that a slight change in any of teachers' psychological capital, organizational commitment, social support, or principals' leadership may create potential a snowball effect influencing teachers' efficacy.

In the real high school settings, teachers' efficacy originates from their psychological capital and develops through a multi-level mediation procedure involving their principals' leadership as the first level of the mediating factor to inspire teachers' social support. Furthermore, teachers' perceptions of social support stimulate their organizational commitment as the secondary hierarchy of mediating effect. Consequently, their commitment as the third level of mediating effect dominantly contributes to teachers' efficacy. In short, teachers' efficacy in the comprehensive senior high school settings is derived and develops through a multi-level mediation procedure by some indirect factors, i.e. principals' leadership, social support, and organizational commitment, rather than merely any single factor.

Psychological capital does not create any direct and significant effect, but it activates through a multi-level mediation effect on teachers' efficacy. The multi-level mediation effects from principals' leadership, social support, and organizational commitment on teachers' efficacy indeed confirm the Bandura's social learning theory [49], [50]. Teachers' efficacy in the real teaching settings are developed and transformed involving a series of complex intrapersonal self-recognition, interpersonal stimulation, and reflective adaption in response to environmental factors [51]. This indirect but continuous influential phenomenon might also reflect the typical Chinese cultures in comprehensive school contexts, which highly value social perspectives.

\section{B. Suggestions}

From the abovementioned research findings, the following suggestions are proposed:

1) Teacher's efficacy is a comprehensive indicator that reflects several concealed phenomena from teachers' inner world, including their psychological capital, organizational commitment, and their perspectives on social support and principals' leadership. School administrators are therefore suggested to deeply understand the factor structure and cause-effect relation for better personnel administration and teachers' achievement through their efficacy.

2) It takes successive and accumulative endeavors to influence teachers' efficacy that barely originates from and/or is influenced by merely any single factor. That is, teachers should carefully build their intrapersonal perspective, such as psychological capital, and keep a good relationship with their school leaders and colleagues for better commitment and efficacy.

3) In order to further understand teachers' efficacy and its constructing factors, future research are suggested to take qualitative research method for objective observation on teachers' career behaviors, such as teaching performance, personal enthusiasm, and their interaction with school leaders. This outside-in oriented research approach might empirically build the interpretation on the factorial relationship developing teachers' efficacy, 
supplementing the inside-out self-rating questionnaire survey.

\section{REFERENCES}

[1] G. D. Hughes, "Teacher retention: teacher characteristics, school characteristics, organizational characteristics, and teacher efficacy," Journal of Educational Research, vol. 105, no. 4, pp. 245-255, June 2012.

[2] Y. Yang, "Principals' transformational leadership in school improvement," International Journal of Educational Management, vol. 28 , no. 3 , pp. $279-288,2014$

[3] M. Amin, S. Shah, and I. Tatlah, "Impact of principals'/directors' leadership styles on job satisfaction of the faculty members: Perceptions of the faculty members in a Public University of Punjab, Pakistan," Journal of Research \& Reflections in Education (JRRE), vol. 7, no. 2, pp. 97-112, December 2013.

[4] V. Gupta and S. Singh, "Psychological capital as a mediator of the relationship between leadership and creative performance behaviors: Empirical evidence from the Indian R\&D sector," International Journal of Human Resource Management, vol. 25, no. 10, pp. 1373-1394, 2014.

[5] S. R. Chesnut and T. A. Cullen, "Effects of self-efficacy, emotional intelligence, and perceptions of future work environment on preservice teacher commitment," Teacher Educator, vol. 49, no. 2, pp. 116-132, March 2014.

[6] A. Aydin, Y. Sarier, and Ş. Uysal, "The effect of school principals' leadership styles on teachers' organizational commitment and job satisfaction," Educational Sciences: Theory and Practice, vol. 13, no. 2, pp. 806-811, Spring 2013.

[7] W. Damon, "Dispositions and teacher assessment the need for a more rigorous definition," Journal of Teacher Education, vol. 58, no. 5, pp. 365-369, Dec. 2007

[8] A. Bandura, Self-Efficacy: The Exercise of Control, New York, NY: Freeman and Company, 1997.

[9] C. J. Egyed and R. J. Short, "Teacher self-efficacy, burnout, experience and decision to refer a disruptive student," School Psychological International, vol. 27, no. 4, pp. 462-474, Oct. 2006.

[10] I. A. Freidman, "Self-efficacy and burnout in teaching: the importance of interpersonal-relations efficacy," Social Psychological of Education, vol. 6, no. 3 pp. 191-215, September 2003.

[11] J. H. Stronge and J. L. Hindman, The Teacher Quality Index: A Protocol for Teacher Selection, Alexandria: Association for Supervision and Curriculum Development, 2006.

[12] M. Tschannen-Moran and A. W. Hoy, "Teacher Efficacy: Capturing an elusive construct," Teaching and Teacher Education, vol. 17, pp. 783-805, 2001.

[13] J. Y. Yang, "Teacher efficacy and college English teaching," Asia-Pacific Science and Culture Journal, vol. 1, no. 1, pp. 34-42, 2011.

[14] L. Frase, Ashton's Efficacy Research. Encyclopedia of Educational Leadership and Administration, vol. 1, Thousand Oaks: Sage, 2006.

[15] J. Schaefer, Impact of Teacher Efficacy on Teacher Attitudes toward Classroom Inclusion (Order No. 3403243), 2010.

[16] J. C. Rost, Leadership in the Twenty-First Century, New York: Praeger, 1991.

[17] A. Jargo and V. Room, "The role of situation in leadership," American Psychologist, vol. 62. No. 1, pp. 17-24, January 2007.

[18] M. P. Hobson, "Teacher perceptions of change in leadership roles and activities as a result of participation in a science education leadership program (Order No. 3384250)," 2009.

[19] R. Evans, The Human Side of School Change: Reform, Resistance and the Real-Life Problems of Innovation, San Francisco: Jossey-Bass, 1996.

[20] P. A. Wasley, Teachers Who Lead: The Rhetoric of Reform and the Realities of Practice, New York: Teachers College Press, 1991.

[21] E. Wiggenton, "A vision of teacher leadership: in the teachers' voice," Washington, DC: National Education Association.

[22] J. York-Barr and K. Duke, "What do we know about teacher leadership? Findings from two decades of scholarship," Review of Educational Research, vol. 74, no. 3, pp. 255-316, 2004.

[23] J. M. Kouzes and B. Z. Posner, The Leadership Practices Inventory (LPI): Facilitator Guide Package, 3rd ed, San Francisco: Jossey-Bass, 2003.

[24] F. Luthans, C. M. Youssef, and B. J. Avolio, Psychological Capital: Developing the Human Competitive Edge, New York: Oxford University Press, Inc, 2007.
[25] S. Mehrabi, H. Babri, M. Frohar, B. Khabazuan, and S. Salili, "Investigating the relationship between organizational psychological capital and meaning in the employees "work (Shahid Beheshti University as a Case Study)," International Journal of Human Resource Studies, vol. 3, no. 2, pp. 42-50, 2013.

[26] F. Luthans, J. B. Avey, and J. L. Patera, "Experimental analysis of a web-based intervention to develop positive psychological capital," Journal of Academy of Management Learning and Education, vol. 7, no. 2. pp. 209-221, 2008.

[27] J. B. Avey, J. L. Nimnicht, and N. G. Pigeon, "Two field studies examining the association between positive psychological capital and employee performance," Leadership \& Organizational Development Journal, volume. 31, issue 5, pp. 384-401, 2010.

[28] S. Mortazavi, S. V. Yazdi, and A. Amini, "The role of the psychological capital on quality of work life and organizational performance. Interdisciplinary," Journal of Contemporary Research in Business, vol. 4, no. 2, pp. 206-217, 2012.

[29] N. J. Allen and J. P. Meyer, "The measurement and antecedents of affective, continuance and normative commitment to the organizational," Journal of Occupational, vol. 63, issue 1, pp. 1-18, March 1990.

[30] N. Skinner, Workforce Development TIPS (Theory into Practice Strategies): A Resource Kit for the Alcohol and Other Drugs Field National Centre for Education and Training on Addiction (NCETA), Flinders University, Adelaide, Australia, 2005.

[31] T. Limpanitgul, P. Boonchoo, and S. Photiyarach, "Coworker support and organisational commitment: A comparative study of Thai employees working in Thai and American airlines," Journal of Hospitality and Tourism Management, vol. 21, pp. 100-107, December 2014

[32] S. Garg and R. L. Dhar, "Effects of stress, LMX and perceived organizational support on service quality: Mediating effects of organizational commitment," Journal of Hospitality and Tourism Management, vol. 21, pp. 64-75, September 2014.

[33] C. Celep and O. E. Yilmazturk, "The relationship among organizational trust, multidimensional organizational commitment and perceived organizational support in educational organizations," Procedia-Social and Behavioral Sciences, vol. 46, pp. 5763-5776, 2012.

[34] C. Demir, B. Sahin, K. Teke, M. Ucar, and O. Kursun, "Organizational commitment of military physicians," Military Medicine, vol. 174, no. 9, pp. 929-35, 2009.

[35] R. Eisenberger, P. Fasolo, and V. Davis-LaMastro, "Perceived organizational support and employee diligence, commitment, and innovation," Journal of Applied Psychological, vol. 75, no. 1, pp. 51-59, Feb. 1990.

[36] C. Perryer and C. Jordan, "The influence of leader behaviors on organizational commitment: a study in the Australian public sector," Intl Journal of Public Administration, vol. 28, no. 5, pp. 379-396, February 2007

[37] O. R. Mahdi, E. S. Mohd, and M. K. Almsafir, "Empirical study on the impact of leadership behavior on organizational commitment in plantation companies in Malaysia," Procedia: Social and Behavioral Sciences, vol. 109, pp. 1076-1087, 2014

[38] A. M. Shurbagi, "The relationship between transformational leadership style job satisfaction and the effect of organizational commitment," International Business Research, vol. 7, no. 11, pp. 126-138, 2014.

[39] Y. Ramchunder and N. Martins, "The role of self-efficacy, emotional intelligence and leadership style as attributes of leadership effectiveness," SA Journal of Industrial Psychology, vol. 40, no. 1, pp. 1-11, May 2014

[40] I. H. Amzat and A. K. Ali, "The relationship between the leadership styles of heads of departments and academic staff's self-efficacy in a selected Malaysian Islamic University," Interdisciplinary Journal of Contemporary Research in Business, vol. 3, no. 1, pp. 940-964, 2011.

[41] H. Chi, H. Yeh, and S. Choum, "The organizational commitment, personality traits and teaching efficacy of junior high school teachers: the meditating effect of job involvement," The Journal of Human Resource and Adult Learning, vol. 9, no. 2, pp. 131-142, 2013.

[42] D. T. Dovina and S. Karunanidhi, "The influence of positive psychological capital and work attitude on the performance of employees in ITES," Indian Journal of Positive Psychology, vol. 4, no. 1, pp. 1-6, 2013

[43] S. Saprayapa, A. Tuicomepee, and R. Watakakosol, "Validation of Psychological Capital Questionnaire in Thai Employees, Official Conference Proceedings," The Asian Conference on Psychology \& the Behavioral Sciences, pp. 394-399, 2013. 
[44] E. Ray and K. Miller, "Social support, home/work stress, and burnout: Who can help?," Journal of Applied Behavioral Science, vol. 30, no. 3, pp. 357-373, September 1994.

[45] R. P. Bagozzi and Y. Yi, "On the evaluation of structural equation models," Journal of the Academy of Marketing Science, vol. 16, issue 1, pp. 74-94, March 1988.

[46] D. P. MacKinnon, Introduction to Statistical Mediation Analysis, Mahwah, NJ: Erlbaum, 2008

[47] K. L. Zellars, P. L. Perrewe, A. M. Rossi, B. J. Tepper, and G. R. Ferris, "Moderating effects of political skill, perceived control, and job-related self-efficacy on the relationship between negative affectivity and physiological strain," Journal of Organizational Behavior, vol. 29, no. 5, pp. 549-571, July 2008.

[48] A. Bandura, Social Foundations of Thought and Action: A Social Cognitive Theory, Englewood Cliffs, NJ: Prentice-Hall, Inc, 1986.

[49] A. Bandura, "Social cognitive theory of posttraumatic recovery: The role of perceived self-efficacy," Behaviour Research and Therapy, vol. 42, issue 10, pp. 1129-1148, October 2004.

[50] K. Sandstrom, D. Martin, and G. A. Fine, "Symbolic interactionism at the end of the century," in G. Ritzer and B. Smart, The Handbook of Social Theory, pp. 217-231, London: Sage Press, 2001.

[51] D. Gibson, "Face to face: Toward a sociological theory of interpersonal behavior (review)," Social Forces, vol. 82, no. 1, pp. 404-406, Sept. 2003.

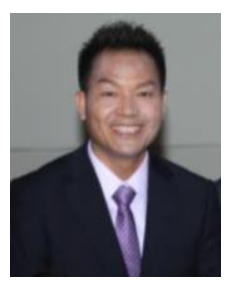

Mingchang Wu received his Ph.D from Purdue University. He is currently a full professor and the dean in National Yunlin University of Science and Technology, Taiwan. He is dedicated to academic research in the field of university development and program evaluation.

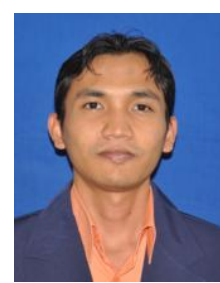

Marsono is a $\mathrm{Ph} . \mathrm{D}$ student at Graduate school of Technological and Vocational Education, National Yunlin University of Science and Technology, Taiwan. He got a doctoral degree scholarship in 2013 from the scheme of the Indonesian Directorate General of Higher Education (DIKTI). He received his M.Ed at Technological and Vocational Education in 2010 from Yogyakarta State University, Indonesia. He is also a lecturer at Mechanical Engineering Education Department, in Malang State University, Indonesia. 